\section{事 例}

トリクロロエチレンによると考えられる胃潰 湯を合併した腸管のう腫様気腫の 1 例

A Case Report of Pneumatosis Cystoides Intestinalis Accompanied with Gastric

Ulcer Resulting from Occupational

Trichloroethylene Exposure

Key words: pheumatosis cystoides intestinalis; gastric ulcer; trichloroethylene; occupational exposure

最近, トリクロロエチレン (Tri) による脱脂洗浄作業 に從事していた患者で，胃沿掦を合併した晹管のら腫様 気腯 (PCI) を経験した。

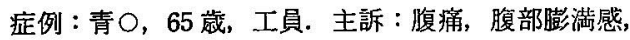
便秘. 既往歴：特にない. 職歷：60歳をで計器会社に勤 務していた．昭和 59 年 10 月同社を定年退職し，染装会 社に再就職した．現病歴：昭和 61 年 3 月より Tri を用 いて部品の洗浄作業に従事するようになった。洗浄槽は $150 \times 100 \times 120 \mathrm{~cm}$ の大きさで，部品をハケや手で直接 洗っていた. 1 日 8 時間加 10 時間作業し，仕事を終 る頃には䤂醇態となり，ふらららして自分でも何をや っているかわからない状態であった．昭和 61 年 5 月頃 より腹部膨満感を批ぼえるようになり，排ガスも多くな った，その後，時々左腹痛を認めるよらになり，便秘の 傾向となった，症状が続くので，昭和 62 年 1 月 19 日近 医より紹介され，1月 21 日精査のため入院した．入院 時現症：体格中等，栄養良好. 血厈 $110 / 48 \mathrm{mmHg}$. 貝 血著明，黄㡺はない、リンパ節触知しない，胸部は正 常. 腹部は左上腹部に圧痛を認めたが，肝・脾は触知し ない，下肢に浮腫なく神経学的にも異常なかった，検查 成績 : 尿検查正常. 便潜血 (一). 末梢血では，RBC 264 $\times 10^{4}, \mathrm{Hb} 7.9 \mathrm{~g} / \mathrm{dl}, \mathrm{Ht} 23.3 \%$, WBC 5, 300, Plt 34.6 $\times 10^{4}$ ， ESR $42 \mathrm{~mm} / \mathrm{h}$ と貧血が著明であった。，血液生 化学では, T.P. $5.9 \mathrm{~g} / \mathrm{d} 1$, BUN $32.7 \mathrm{mg} / \mathrm{dl}$, creatinine $1.2 \mathrm{mg} / \mathrm{dl}, \mathrm{Fe} 37 \mu \mathrm{g} / \mathrm{d} 1$ と軽度異常を認めた以外, 肝 機能および電解質等は正常であった．血清学的には， $\operatorname{CRP}(-)$, \%反応(-), CEA $0.8 \mathrm{ng} / \mathrm{ml}, \operatorname{IgG} 865 \mathrm{mg} /$ dl, IgA $139 \mathrm{mg} / \mathrm{dl}, I g M 59 \mathrm{mg} / \mathrm{ml}$ であった. 尿中 Tri の代謝産物は，1月 16 日まで作業し，作業中止後 5 日たっていたが, 棇三塩化物 $47.6 \mathrm{mg} / l$, 三塩化酶酸 $44.7 \mathrm{mg} / l$ と著明に上晨していた，尚，尿中馬尿酸 $0.245 \mathrm{~g} / l$, ィチル馬尿酸 $0.007 \mathrm{~g} / l$ と正常であった. 腹

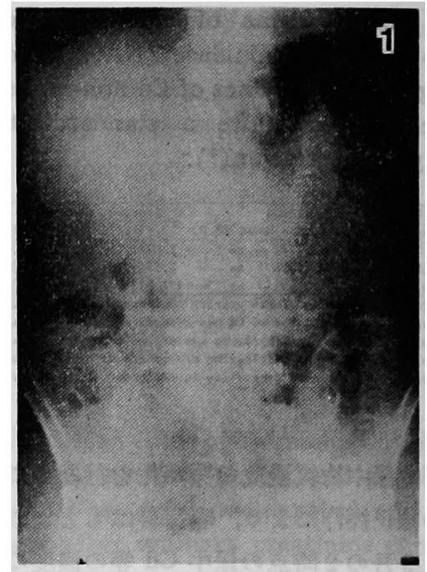

Fig. 1. Plain abdominal X-ray film.

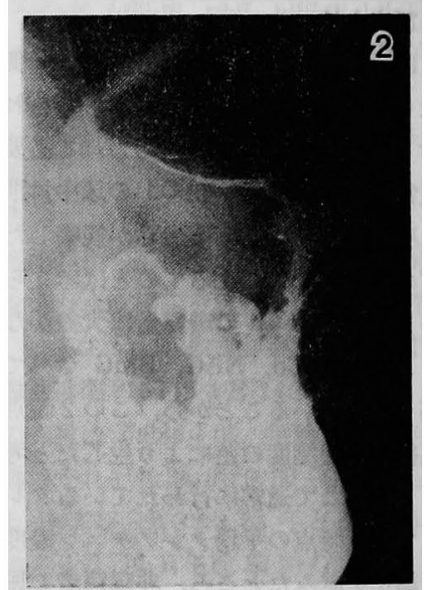

Fig.2. Upper gastrointestinal X-ray film.

部単純X線写真 (Fig.1) では, 左腹部に腸管のガス像に 重なって，蜂窝状の輪状影を認めた，上部消化管透視 (Fig.2）では，胃体上部後壁にかなり深いニッシェを范 めた．胃内視鏡では，母指頭大の $\mathrm{Ul}_{3}$ の良性溃度であっ た. 注腸透視 (Fig.3) では， S 字状結腸から下行結腸火 かけ多数ののう胞状の陰影を認め，辺縁はヒイラギの葉 状であった．同部は拡張し，この部のパリウムは 1 週間 以上にわたって存在し，この部の腸管の機能低下をらか がわせた，大腸内視鏡では，直腸上部から上方に，大小 不同, 表面平滑の半球状の隆起が密集してみられた。 の隆起は，錋子で生検すると破れて平坦化した．生検鿬 本では，粘膜下部に多核巨細胞の集簇を認め，PCI を筑 わせる所見であった，入院後経過：以上の所見より，胃 潰瘍を伴った PCI と考えられた。輸血，抗㵋掦郕の投 与により筫血, 胃潰瘍は急速に改善した. PCI そ対して 


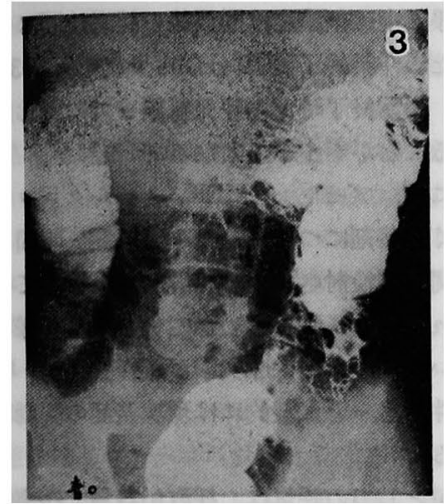

Fig.3. Barium enema examination.

は，释過観察とした. 徐々に腹痛，腹部膨満感は消失， 便通も正常化した. 尿中総三塩化物, 三塩化酷酸も入院 2 週間ほどで正常化した. 3 月 10 日の注腸透視では， のら胞状の陰影はかなり減少したが，また残存し，同部 の抾張および機能低下をらかがわせる所見も認めたが， かなり改善しているので 3 月 25 日退院した. 現在, 外 来で経過観察中である.

\section{考 察}

PCI は比較的まれな疾患であり，続発性と原発性にわ けられる. 佐藤らリの検討では，続発性のものは小腸に 認められることが多く, 原発性のものは $\mathrm{S}$ 字状結腸に好 発するという.

PCI の発症機序2) として機械説, 細菌説, その他が考 えられている. 原発性 PCI と Tri 暴露との関係につい ては，山口゙,4，佐藤らいにより注目され，雨者の間には かなり密接な関係が疑われているが，いまた確定的では ない。荒井ららは，ラットを用いたTri 暴露実騟におい て，PCI 作成に失敗したと報告している. 山ロられる Tri 使用工場における疫学調查で, PCI は発見されず， PCI と Tri との関係を積極的に関連づける成績はえら れなかったとしている.

しかし，本例においては，以前には全く異常を認めな かったのに, Tri 洗浄作業に従事するようになってから 調子が悪くなり，腹痛，腹部膨満感，便秘を諗めるよう になったと患者が訴えていること，尿中総三塩化物，三 塩化醀酸の定量で，作業中止後 5 日ほどたっているにも かかわらず，異常高値を示していることなどより，本例 の PCI と Tri 暴露との間には密接な関係があるものと
推定ざれる。

また本例において，Triによる洗浄作業開始後約 3 か 月という比較的短期間より自覚症状が出現している点 は，作策内容から推定して，局所排気装監が不十分であ り，作業の仕方も洗浄槽に顔を入れる手作業が多く，本人 の訴えより作業後酪酊状態であったなと，Tri 染露量が かなり多かったことと関係しているるのと考えられる.

原発性 PCI において症状は, 腹部の鈍痛, 腹部膨満 感, 便秘, 時に粘血便が多く、これは腸管壁内にのう腫 様気腫が累々と生し，内腔の狭小化をきたして，通過障 害を起こすためと説明されている。

しかし，本例について観察したかぎりでは， $\mathrm{s}$ 字状結 腸から下行結腸の霍患部では，むしろ腸管は緊張を失 い，内腔は拡大し，便通が毎日あったにもかかわらず， 造影剤は同部に I 週間近くにわたって㴖溜しており，機 能低下の所見を認めた，それゆえ，腹部膨満感，便秘な どの症状は，罹患部腸管の機能低下による症状と考えら れるが，これはTri の強い麻醉作用を考学るとき，大変 興味ある所見と考えられる。

Tri 暴露と PCI 発生との関係は，いまた研究の緹に ついたに過ぎないとの観があり，今後さらに症例の集 積，疫学調查および動物実験によるららつけなどが必要 と考えられる.

\section{文 献}

1）佐藤章夫，山口孝太郎，中島民江. トリクロロエチレン と腸管のう腫様気腫. 産業医学 1986; $28: 57-62$.

2) Galandiuk S,F azio VW, Pneumatosis cystoides intestinalis : a review of the literature. Dis Colon Rectum 1986; 29 : 358-363.

3) Yamaguchi $\mathrm{K}$, Shirai $\mathrm{T}$, Shimakura $\mathrm{K}$ et al. Pneumatosis cystoides intestinalis and trichloroethylene exposure. Am J Gastroent 1985; 80 : 753757.

4）山口孝太郎，白井 忠，嶋合勝秀汪か，大腸腸管のう腫 様気連の湢床疫学的検討. 日消誌 $1985 ; 82: 1710-1716$.

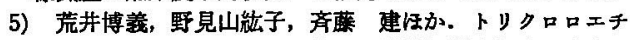
レンKよる実験的ラット渴管のう腫様気盾症作成の失敗. 産業医学 $1986 ; 28: 275-278$.

\section{北原多喜}

市立岡谷病院内科

Masaki KITAHARA

Department of Internal Medicine, Okaya City Hospital, Okaya, Japan

昭和 62 年 4 月 9 日受付

通信先 : 北原あて, Reprint requests to M. Kitahara 